\title{
REMOVAL OF IMPORTANT PARAMETER FROM CAR WASH WASTEWATER - A REVIEW
}

\author{
Nadzirah, Z. ${ }^{1, a^{*}}$ Nor Haslina, $\mathrm{H}^{2, \mathrm{~b}}$ and Rafidah, $\mathrm{H}^{3, \mathrm{c}}$ \\ ${ }^{1}$ Department of Water and Environment, Faculty of Civil Engineering and Environment, University \\ Tun Hussein Onn Malaysia, \\ ${ }^{2,3}$ Department of Water and Environment, Faculty of Civil Engineering Technology, University Tun \\ Hussein Onn Malaysia \\ anadzayadi@gmail.com, ${ }^{\mathrm{b}}$ haslina@uthm.edu.my, ${ }^{\mathrm{C}}$ rafidahh@uthm.edu.my
}

Keywords: chemical oxygen demand, oil and grease, surfactant

\begin{abstract}
Huge quantity of water consumed per car and the various chemical agents used in car wash activities discharged the untreated effluents into the stormwater system and eventually ending up in our lakes, rivers and oceans [1]. The accumulated sediments from vehicle wash contain contaminants that reach concentrations where the sludge is considered as a controlled or hazardous waste, including of metals, elevated levels of oil and grease, and the unacceptable levels of acidity or alkalinity [2]. This paper provides a comprehensive review of car wash wastewater data analyzes regarding the wastewater discharges, as well as contaminant levels of car wash activities. Besides, the further extensive research on treatments used in the car wash industry for pollutant removal routes, including the removal efficiency of pollutants has also been highlighted. The expansion of the review on the influence of the treatment indicates that, the effeciency on removal pollutants depends on the treatment used. Overall, the review illustrates the necessity of a profound knowledge on the car wash wastewater with an extensive list of common treatment of car wash wastewater in providing the alternative way for on-site treatment for car wash outlet in treating the effluent before discharging into water bodies. Hence, decreases the pollution governing environmental, operational parameters, and the treatment performances of low cost system in treating the car wash wastewater.
\end{abstract}

\subsection{Introduction}

In this worldwide, about 20 million hectares of land are occupied with treated and untreated wastewater use. Malaysia has their own environmental quality regulations, but seldom enforced to the car wash industry [3]. The car wash discharge system cannot mix with the stormwater system, where it can contribute to the permeation of other pollutants towards the aquatic animals [9,17]. A car wash is defined as a non-domestic installation for external cleaning of cars, offering consumers a practical way to wash dirts from their automobiles [3,4]. The Environmental Pollution Agency rose awareness of the following list from vehicle washes such as detergents, heavy metals, oil, grease, polycylic aromatic hydrocarbons (PAH's) and volatile organic compounds (VOC's) $[3,12,14]$. Oil and grease contain toxic substances which are carcinogenic to human beings whereas, the accumulation of heavy metals concentrations reducing microbial activity, lead to the inhibition of chlorophyll synthesis which hazard to the ecosystem $[12,18,19]$. Moreover, the synthetic anionic surfactants, commonly linear alkyl sulphate (LAS) and sodium dodecyl sulphate (SDS) components from detergent of car wash activities are very slow to biodegrade into the environment, lowering the oxygenation potential and hence, kills the waterborne organisms [8]. Hence, the concentration and severity each element should be assessed and considered in treating the pollutants. In this review, an extensive lists of treatment for car wash wastewater from conventional methods has been compiled and discussed. The efficiency of each system in removing pollutants were analyzed and compared. 


\subsection{Car wash wastewater treatment}

\subsubsection{Ultrafiltration (UF) and nanofiltration (NF) membrane}

Generally, the membrane technologies commonly used in wastewater treatment, including of UF and NF membrane [12]. With the aid of the UF membrane, the biodegradable organics, colloids and some viruses can be removed as presented in Table 1. UF membrane and NF membrane have different performances in treating wastewater $[10,13,15,18]$. The oil emulsion are the main pollutant observed in car wash wastewater, commonly by the detection of PAH's in lubricant oils. A study reported the oil emulsion was not absorbed directly to the NF membrane due to the negative charge repulsion between anionic emulsion and membrane surface, where the NF membrane removing $98 \%$ of pollutants of total organic carbon compared to UF membrane [15]. The UF membrane is ineffective in removing conductivity and total dissolved solids removal, because the membrane has flux deterioration and low flux recovery rate [14]. Apart from using the UF and NF membrane itself, the performance of hybrid system combining the bio-carriers and non-woven membrane filtration was explored. Rather than the UF membrane, the non-woven material of the membrane separating the suspended solid at lower operating pressure and reasonable cost. The bio-carriers have large porous structures of surfaces allowed it to trap the attached growth microorganisms and then degrading the biodegradable matter, and removing the organic removal of car wash wastewater [13].

Table 1: Car wash wastewater treatment systems

\begin{tabular}{|c|c|c|c|c|c|}
\hline \multirow[t]{2}{*}{ No } & \multirow[t]{2}{*}{ Type of treatment } & \multicolumn{3}{|c|}{ Results } & \multirow[t]{2}{*}{ Reference } \\
\hline & & & Parameter & Percentage removal $(\%)$ & \\
\hline \multirow[t]{18}{*}{1} & \multirow[t]{18}{*}{ Membranes } & Ultrafiltration membrane & \multirow[t]{7}{*}{ TOC } & & \multirow[t]{7}{*}{15} \\
\hline & & PS-100 & & 75 & \\
\hline & & C-100 & & 75 & \\
\hline & & $\mathrm{C}-30$ & & 75 & \\
\hline & & GM & & 75 & \\
\hline & & Nanofiltration membrane & & \multirow[b]{2}{*}{98} & \\
\hline & & DK & & & \\
\hline & & Ultrafiltration membrane & \multirow[t]{5}{*}{ COD } & & \multirow[t]{5}{*}{13} \\
\hline & & PVDF 100 & & $56.1-82.4$ & \\
\hline & & PES 30 & & $54.9-83.9$ & \\
\hline & & Nanofiltration membrane & & & \\
\hline & & NF 270 & & $70.9-91.5$ & \\
\hline & & \multirow[t]{4}{*}{ Ultrafiltration membrane } & TDS & 82.2 & \multirow[t]{4}{*}{18} \\
\hline & & & TSS & 81.08 & \\
\hline & & & COD & 67.5 & \\
\hline & & & O\&G & 74.97 & \\
\hline & & \multirow{2}{*}{$\begin{array}{l}\text { Non-woven membrane filtration with bio- } \\
\text { carriers }\end{array}$} & COD & 70.15 & \multirow[t]{2}{*}{10} \\
\hline & & & SS & 95.65 & \\
\hline \multirow[t]{7}{*}{2} & \multirow[t]{7}{*}{ Oil separator } & \multirow[t]{6}{*}{ Gravity oil separator } & $\mathrm{O} \& \mathrm{G}$ & 80 & \multirow[t]{6}{*}{8} \\
\hline & & & TSS & 88 & \\
\hline & & & VSS & 87 & \\
\hline & & & TDS & 40 & \\
\hline & & & VDS & 46 & \\
\hline & & & COD & 74 & \\
\hline & & Oil separator & O\&G & $73-98.47$ & 2 \\
\hline \multirow[t]{8}{*}{3} & \multirow{8}{*}{$\begin{array}{l}\text { Chemical oxidation by } \\
\text { aeration, alum }(80 \mathrm{mg} / \mathrm{L}) \text {, } \\
\text { waste hydrogen peroxide } \\
(2.5 \mathrm{~m} / \mathrm{L})\end{array}$} & & O\&G & 96 & \multirow[t]{8}{*}{3} \\
\hline & & & COD & 93 & \\
\hline & & & TDS & 74 & \\
\hline & & & $\mathrm{pH}$ & 14 & \\
\hline & & & Conductivity & 26 & \\
\hline & & & \begin{tabular}{|l} 
Turbidity \\
\end{tabular} & 94 & \\
\hline & & & $\mathrm{DO}$ & 78 & \\
\hline & & & TS & 91 & \\
\hline
\end{tabular}


Table 1 continued

\begin{tabular}{|c|c|c|c|c|c|c|}
\hline \multirow[t]{4}{*}{4} & \multirow{4}{*}{$\begin{array}{l}\text { Flocculation column } \\
\text { flotation, sand filtration and } \\
\text { final chlorination }\end{array}$} & & & TSS & 91 & \multirow[t]{4}{*}{21} \\
\hline & & & & Turbidity & 91 & \\
\hline & & & & $\mathrm{TC}$ & 95 & \\
\hline & & & & E. Coli & 99 & \\
\hline \multirow[t]{8}{*}{5} & \multirow{8}{*}{$\begin{array}{l}\text { Hydrophilic and } \\
\text { hydrophobic membrane }\end{array}$} & Hydrophilic membrane & \multirow[t]{8}{*}{ Surfactant } & Nonionic & $93-99$ & \multirow[t]{8}{*}{4} \\
\hline & & NF270 & & Cationic & $83-99$ & \\
\hline & & & & Anionic & $85-100$ & \\
\hline & & & & COD & $78-98$ & \\
\hline & & Hydrophobic membrane & & Nonionic & $30-91$ & \\
\hline & & \multirow[t]{3}{*}{ NFPES 10} & & Cationic & $27-71$ & \\
\hline & & & & Anionic & $53-100$ & \\
\hline & & & & COD & $33-78$ & \\
\hline
\end{tabular}

\subsubsection{Oil separator}

The oil separator was designed to ensure the removal of all light oils escaped from the oil skimmer in the settling tank. In this study, the authors suggested the treated water from the study can be used for wash and pre rinse for the car washes [2]. Besides, the conventional oil separator has less of specific standards recommended for the design of gravity separators for car wash stations. Based on the performance of the gravity oil separators observed in the car wash industries, the authors concluded the system does not allow producing an effluent that complies with the discharge limits established in the sewage system. The removal of oil and grease (O\&G), total suspended solid (TSS), volatile suspended solid (VSS), total dissolved solid (TDS), and chemical oxygen demand (COD) exhibited better results of removal by using gravity oil separators. However, the results of chemical oxygen demand and total suspended solid were not followed the sewer discharge standards [8].

\subsubsection{Chemical oxidation}

The chemical oxidation including process of aeration for oil water separation, alum treatment for pollutant removal with aid of hydrogen peroxide. The aeration responsible to separate the oil and water by trapping the oil by the air bubbles carrying oxygen. Total chemical oxygen demand reduction after going through the overall processes was $93 \%$. The increase dosage of alum alone for the treatment does not meet the desired discharge standard. The aid of hydrogen peroxide creates positively charged and polynuclear species, resulting charged compounds react with colloids attained with negative ions present in the wastewater. The gravity force helps in removing of suspended solids and chemical oxygen demand. Moreover, the alum act as a coagulant whereas the hydrogen peroxide reducing the concentration of chemical oxygen demand from car wash wastewater. The further treatment by waste hydrogen peroxide were done subsequently after the aeration and addition of alum processes. The present study has potential to reduce the cost of water treatment and requires less space without any $\mathrm{pH}$ control [3].

\subsubsection{Flocculation column flotation (FCF), sand filtration (SF) and final chlorination (FC)}

Flocculation allows the removal of organic matters and colours of wastewater. However, the treatment should be furthered studied with the other processes, depends on the proper selection of flocculant and proper designed of system to improve the operations [16]. Treatment of car wash wastewater by flocculation column flotation experimented in Brazil. However, the results obtained were high for turbidity and colour due to the existence of bubbles, the presence low surface tension and oil and grease which yielding the light flocs [19]. Another study in 2013 have combined a bench study of FCF and SF followed by a FC for car wash wastewater treatment. The SF process helps in removing the pathogenic microorganisms from car wash wastewater and the process of 
chlorination inhibit the growth of E. Coli. The last stage of treatment, final chlorination helps in removing the pathogens and other microorganisms that may have passed by SF. During the process, the chlorine disinfection deactivated the microorganism lives resulting death of different mechanisms. As the results, the coupled system of the treatment effective with removal of E. Coli, TSS, turbidity, TOC were $99 \%, 91 \%, 91 \%$ and $95 \%$ respectively [21].

\subsubsection{Hydrophilic and hydrophobic membrane}

The hydrophilic and hydrophobic membrane has a high water permeability with different surfactants and the membrane fouling have been studied. The results show that the hydrophilic membrane was more efficient in removing different type of surfactants compared with hydrophobic membrane. Hydrophilic membrane was not damaged after undergoing the treatment of car washes. Moreover, there was no chemical needed to enhance the membrane flux of the membrane. The authors have concluded that the nanofiltration membrane can also be used for recycling wastewater [4].

\subsection{Conclusions}

There was lack information regarding the treatment used for car wash wastewater treatment system. In spite of using conventional methods and simple treatment strategies for car wash wastewater treatment system, a wide range of any low cost potential wastewater treatment should have been investigated and studied. Some of the treatment system was found to be quite satisfactory in removing pollutants. However, there is a strong need to conduct extensive research due to the reuse and reclaiming of car wash wastewater as other potential to reduce scarcity in worldwide rather than disposed it. If it is possible in developing other low cost and simple treatment differ from the treatment that have been reviewed, then these treatments may offer many advantages and commercially attracting consumers and developers of car wash stations, and hence contribute to the way of minimizing pollutants of car wash wastewater.

\section{Acknowledgement}

This work is funded by University Tun Hussein Onn Malaysia of Postgraduate Incentive Research Grant (GIPS), Vot No. : 1404. Expression of gratitude is presented to Authorized Translator for the invaluable comments and suggestions.

\section{References}

[1] Abagale, F. K., Sarpong, D. A., Ojediran, J. O., Osei-Agyemang, R., Shaibu, A. G., and Birteeb, P. T. Heavy Metal Concentration In Wastewater From Car Washing Bays Used For Agriculture In The Tamale Metropolis, Ghana. International Journal Of Current Research. 2013. 5(6): $1571-1576$.

[2] Al-Odwani, A., Ahmed, A., and Hamad, S. B. Carwash Water Reclamation in Kuwait. Desalination. 2007. 17 - 28.

[3] Bhatti, Z. A., Mahmood, Q., Raja, I. A., Malik, A. H. and Wu, D. Chemical oxidation of Carwash Industry Wastewater As An Effort to Decrease Water Pollution. 2011. Journal of Physics and Chemistry of the Earth. 36. 465-469.

[4] Boussu, K., Kindts, C., Vandecasteele, C., and Bruggen, B. V. D. Applicability of Nanofiltration in the Carwash Industry. Separation and Purification Technology. 2007. 54: $139-146$.

[5] Capital Regional District Environmental Services (2007). Environmental Regulations and Best Management Practises: Vehicle Wash Operations in the Capital Regional District (CRD). Regional Source Control Program. Victoria. 
[6] Cobb, A., Warms, M., and Maurer, E. P. Low-Tech Coconut Shell Activated Charcoal Production. International Journal for Service Learning in Engineering. 2012. 7(1): 93-104.

[7] Das, K. K. Electrochemical Treatment of Wastewater Originated from Oil/Gas Production and Car wash. Degree Master. Theses. Lamar University; 2010.

[8] Fall, C., Lopez-Vazquez, C. M., Jimenez-Moleon, M. C., Ba, K. M., Diaz-Delgado, C., Garcia-Pulido, C., and Lucero-Chavez, M. Carwash Wastewaters: Characteristics, Volumes, and Treatability by Gravity Oil Separation. Journal of Revista Mexicana De Ingenieria Quimica. 2007. 6(2): 175-184.

[9] Genuino, H. C., Opembe, N. N., Njagi, E. C., McClain, S. and Suib, S. L. A Review of Hydrofluoric acid and Its Use in the Car Wash Industry. 2012. Journal of Industrial and Engineering Chemistry. 18. 1529-1539.

[10] Hsu, S. K., Chen, C. H., and Chang, W. K. Reclamation of car washing wastewater by a hybrid system combining bio-carriers and non-woven membranes filtration. Desalination and Water Treatment. 2011. 34. 349-353.

[11] Kwach, B. O., and Lalah, J. O. High concentrations of polycyclic aromatic hydrocarbons found in water and sediments of car wash and Kisat areas of Winam Gulf, Lake VictoriaKenya. Bulletin of environmental contamination and toxicology. 2009. 83(5): 727-733.

[12] Lan, Wu., Gang, GE., and Jinbao, W. L. Biodegradation of oil wastewater by free and immobilized Yarrowia lipolytica W29. Journal of Environmental Sciences. 2009. 21(2): 237242.

[13] Lau, W. J., Ismail, A. F., and Firdaus, S. Car wash industry in Malaysia: Treatment of car wash effluent using ultrafiltration and nanofiltration membranes. Separation and Purification Technology. 2013. 26 - 31.

[14] Oknich, J. (2002). Handbook for The Perceived Environmental Impact of Car Washing. Ramsey-Washington Metro Watershed District. Washington.

[15] Panpanit, S. Oily Wastewater Treatment by Coupling Membrane. Doctor of Engineering. Theses. Asian Institute of Technology; 2001.

[16] Petrovic, M., Gonzalez, M., and Barcelo, D. Analysis and removal of emerging contaminants in wastewater and drinking water. Journal of Trends and Analytical Chemistry. 2003. 22(10): 685-696.

[17] Sablayrolles, C., Vialle, C., Vignoles, C., and Vignoles, M. M. Impact of carwash discharge on stormwater quality (Toulouse, France). 2010. Water Science and Technology. 62(12): 2737-2746.

[18] Shete, B. S., and Shinkar, N. P. Use of membrane to treat car wash wastewater. International Journal of Research in Science \& Advanced Technologies. 2014. 3(1): 13-19.

[19] The California Urban Water Conservation Council. Evaluation of Potential Best Management Practices Vehicle Wash Systems - Vehicle Wash Systems. October, 2006.

[20] Zaneti, A. R. N. and Rubio, J. Treatment of washrack wastewater with water recycling by advanced flocculation-column flotation. Desalination. 2009. 8. 146-153.

[21] Zaneti, R. N., Etchepare, R. and Rubio, J. Car wash wastewater treatment and water reuse - A case study. Water science and technology. 2013. 55(11): 953-959. 